\title{
The Potential Minerals of Bay Leaf (Syzygium Polyanthum): To Support Woman in Pregnancy and Breastfeeding
}

\author{
* $1^{\text {st }}$ Dian Aprilia Damayanti \\ Postgraduate Program in Midwifery \\ Health Polytechnic of Semarang \\ Semarang, Indonesia \\ Apriliavalid229@gmail.com \\ $3^{\text {rd }}$ Sutopo Patria Jati \\ Universitas Diponegoro \\ Semarang, Indonesia \\ sutopopatriajati@gmail.com
}

\author{
$2^{\text {nd }}$ Leny Latifah \\ Magelang Health Research and \\ Development Center \\ Ministry of Health, Republic of \\ Indonesia \\ Magelang, Indonesia \\ lenylatifah1@gmail.com \\ $4^{\text {th }}$ Runjati \\ Postgraduate Program in Midwifery \\ Health Polytechnic of Semarang \\ Semarang, Indonesia \\ runjati@yahoo.com
}

\begin{abstract}
Pregnant and Breastfeeding women are vulnerable group for experiencing nutritional deficiencies. Indonesia has many diverse plants which have potential to overcome various micronutrients and macronutrients deficiencies among pregnant and breastfeeding women. One of the plant that has potential to overcome nutritional deficiencies namely Bay Leaf (Syzygium Polyanthum). Previous research on animals has proven that the Bay Leaf extract has high of iron content. This research was conducted by improving the technology of Bay Leaf processing which expected to increase its influence on the body, especially for handling of micronutrients and macronutrients deficiencies.
\end{abstract}

Keywords-Anemia, Daun Salam, Syzygium polyanthum

\section{INTRODUCTION}

Pregnant and Breastfeeding women are vulnerable group for experiencing nutritional deficiencies. During pregnancy, maternal nutrition should contain amount and quality of good nutrition as a prevention of deterioration of fetal health [1]. Whereas during breastfeeding, the nutritional status of the mother has an important role of success of breastfeeding which indicators are measured by the exclusive breastfeeding duration, growth infants and nutritional status of mothers after breastfeeding [2]. Some common micro and macronutrient deficiencies problems that occur in pregnant and breastfeeding women, include: iron deficiency (anemia), vitamin deficiency, magnesium deficiency and also calcium deficiency [3] .

Health problem in pregnancy related to calcium deficiency namely preeclampsia. Preeclampsia is a multisystem disorder that complicates $3 \%-8 \%$ of pregnancies and is one of the main causes of morbidity and mortality worldwide. Overall, 10-15\% of maternal deaths are directly related to preeclampsia and eclampsia. The greatest impact of preeclampsia occurs in developing countries where the incidence of preeclampsia is $20-80 \%$ of maternal mortality. Calcium is good micronutrient that has been studied was related with preeclampsia. Several epidemiological studies in developing countries show an association between decreased calcium intake and preeclampsia. Evidence that changes in calcium metabolism as an important factor on development of preeclampsia.

Several clinical studies discuss about calcium supplementation during pregnancy. A meta-analysis of various randomized control trial studies showed that administration of calcium during pregnancy can prevent the incidence of preeclampsia. Inadequate calcium consumption in pregnant women can cause side effects for mother and fetus and also produce osteopenia, tremors, paresthesias, muscle cramps, tetanus, fetal growth stunted, low birth weight, and low fetal mineralization [4].

Besides calcium, other minerals that are closely related to the incidence of preeclampsia is Magnesium. This mineral works in about 300 enzyme functions in the body's chemical reactions in various forms. The process of protein synthesis, nerve and muscle function, blood glucose control and blood pressure control are some of the body's metabolic functions that are closely related to magnesium [5]. Breastfeeding woman with micronutrient and macronutrient deficiencies (usually in developing countries) can affect to volume and composition of breast milk. So that it takes various efforts for meeting the needs of pregnant and also breastfeeding woman.

Other data obtained related to micro and macronutrient deficiencies, namely: anemia. Globally, the prevalence of anemia in pregnancy around the world is $41.8 \%$. The prevalence of anemia of pregnancy are in Asia around $48.2 \%$, Africa 57.1\%, America 24.1\%, and Europe $25.1 \%$ [6]. Based on the research result of Baseline Health Research (Riskesdas) 2013, the prevalence of anemia in pregnancy in Indonesia was $37.1 \%$ [7]. World Health Organization (WHO) related to anemia since 1995-2011 estimated the prevalence of anemia in women of reproductive age around $29,4 \%$, which value affects more than 528.7 million women [8][9]. The results of this research showed that the prevalence of anemia were higher among breastfeeding 
woman (63\%), followed by pregnancy (59\%), and women who were neither pregnant nor lactating (53\%) [10]. These data are able to represent the number of anemia in breastfeeding woman it includes to the category women of reproductive age. Based on these explanations, it can be concluded that pregnancy and breastfeeding women have increased needs but the fulfillment of both micro and macronutrient nutrients is still not optimal.

Breastfeeding woman are no less important as a group that needs monitoring for meeting their nutrition because breastfeeding woman be the targets of the First Thousand Days Of Life Program in addition to pregnant women, newborns, and children under two years. First Thousand Days Of Life Program is an effort to accelerate community nutrition improvement. Unfortunately, this movement does not show attention to the nutrition of breastfeeding woman. This can be seen from the type of specific and sensitive nutrition interventions during the period of First Thousand Days Of Life program, only focused on pregnant women, newborns, and babies aged six months to two years, while breastfeeding woman did not get the intervention's attention about nutrition. Various government programs have still not reached the target of breastfeeding woman who are actually a nutrition-prone group [11]. So that various efforts are made to improve the health of breastfeeding woman through health promotion activities, monitoring the nutritional status of mothers to be able to create behavioral changes for meeting their nutritional needs.

Indonesia has various plants that has the potential to overcome variety of health problems including micro and macronutrient deficiencies, one of which is by using bay leaves, which are Indonesia plants that are easily to found [12]. Bay leaves has a latin name Syzygium Polyanthum that is one of family Myrtaceae species [13]. This leaf is known as a cooking ingredient in local Indonesian communities with the aim of adding flavor to enhancing the taste food.

Nonetheless now days, bay leaves has been used to overcome various health problems such as antifungal, antibacterial, antimalarial, antidiarrheal, anti-inflammatory, antioxidant, anti-cholesterol, antidiabetic, and hyperuricemia to inhibit the formation of plaque and dental caries [14]. Bay leaves could not induce toxic, teratogenic and genotoxic effects that were shown on animals used as an experiment [15]. Bay leaves contains many nutrients that are good for the body, including minerals. Previous journals explained that bay leaves had high iron content, folic acid, vitamin B12, riboflavin, vitamin B6, vitamin A, vitamin C, vitamin $\mathrm{E}$ and protein. Consuming bay leaves can supply the needs of minerals in the body. Previous research has done bay leaves processing in the form of extracts, which have been proven to have benefits for health. Whereas in this research, bay leaves processing was carried out with Nanotechnology which is the process of making a material so that it has a very small size (around 1-100 nanometers) or commonly referred to as the nanoscale. While the term for materials of this size is often referred to as Nano-crystals and Nano-material [16].

Some of the advantages of nanotechnology are to increase solubility and bioavailability, protect from toxicity, increase pharmacological activity and stability to provide physical protection to the drug. Thus, Nano-sized drugs for herbal medicines will have the potential benefits in increasing activity to overcome a problem [17]. In addition, the advantages of Nanotechnology are to give high concentrations of drugs to the disease because of unique size with high loading capacity, drugs in small particle size that can increase the action of drugs in the blood, the concentration of the drug will persist in the intended organ with a longer period and can reduce the drugs effect [17].

Based on the explanations, it is important to conduct this research to determine the potentials minerals of bay leaves nanoparticles (syzygium polyanthum) to support woman in pregnancy and breastfeeding woman.

\section{OBJECTIVE}

This research aimed to improve the technology of Bay Leaf processing with nanotechnology and determine the mineral content in nanoparticles of Bay Leaf and also the potential to support the minerals needs in pregnancy and breastfeeding woman.

\section{RESEARCH METHOD}

\section{A. Tools and Material}

The tools used in this study are the X-Ray Fluorescence Spectrometer (XRF), ovens, analytical balance, bowl mill, steel bowls and steel balls. While the materials used in this study were bay leaf samples taken from the Tawangmangu area, Central Java.

\section{B. Research Methods}

Simplisia Bay leaves weighed as much as 100 grams. Then the simplicia is blended until smooth. The bay leaf is not mixed with anything. After being delicate, bay leaves were put into the bowl mill for \pm 10 hours to obtain nanoparticle material. The process of making bay leaf nanoparticles also used bowls and steel balls. Steel balls consist of 2 types, namely large balls and small balls. For harder materials, usually use a large steel ball. The Bay leaf (organic material) used a small steel ball so that is was better in producing nanoparticles. After 10 hours in the bowl mill, bay leaves have become nanoparticle material. Samples of bay leaf nanoparticles as much as 1 gram were ready for XRF test.

\section{Analysis}

Samples of bay leaf nanoparticles were measured using an XRF spectrometer. Samples of bay leaf nanoparticles were placed in the XRF chamber. The results of the analysis was print out data about composition and mineral content of bay leaves.

\section{RESULT}

Bay leaf samples taken from Tawangmangu area were begun by harvesting the ripe which were dried. After that, dried bay leaf were refined using a blender. Bay leaves that have been refined, put in a bowl mill about 10 hours to get nano particles from the bay leaf themselves. The XRF analysis results showed the percentage $(\%)$ of the content of the minerals contained in bay leaf samples (syzygium polyanthum). The weight of each mineral is the weight of a 
mineral in each sample of Bay leaf per gram after becoming nano particles.

The final analysis results of mineral content in bay leaves (Syzygium Polyanthum) were shown in the following figure:

\section{A. Macro Minerals Of Bay Leaf (Syzygium Polyanthum)}

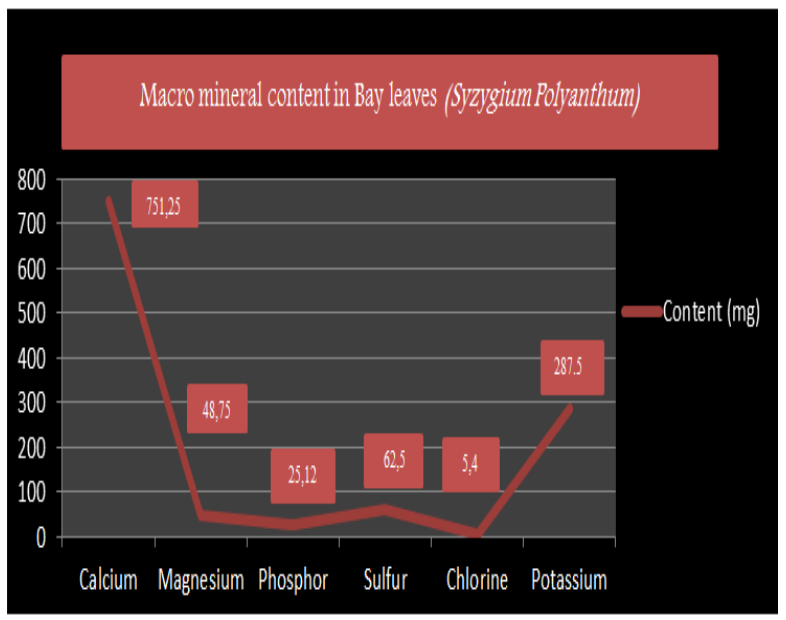

Fig. 1. Macro Mineral Content in Bay Leaves (Syzygium Polyanthum)

Based on the data in Figure 1, it was concluded that there are several types of macro minerals contained in Bay Leaves (Syzygium Polyanthum), including: Calcium (751.25 mg per gram), Magnesium (48.75 mg per gram), Phosphorus (25.15 mg per gram), Sulfur (62.5 mg per gram), Chlorine (5.4 mg per gram) and Potassium (287.5 mg per gram). From the elaboration of these data, it is known that the highest macro mineral content in Bay leaves (Syzygium Polyanthum) is Calcium

\section{B. Micro Minerals Of Bay Leaf (Syzygium Polyanthum)}

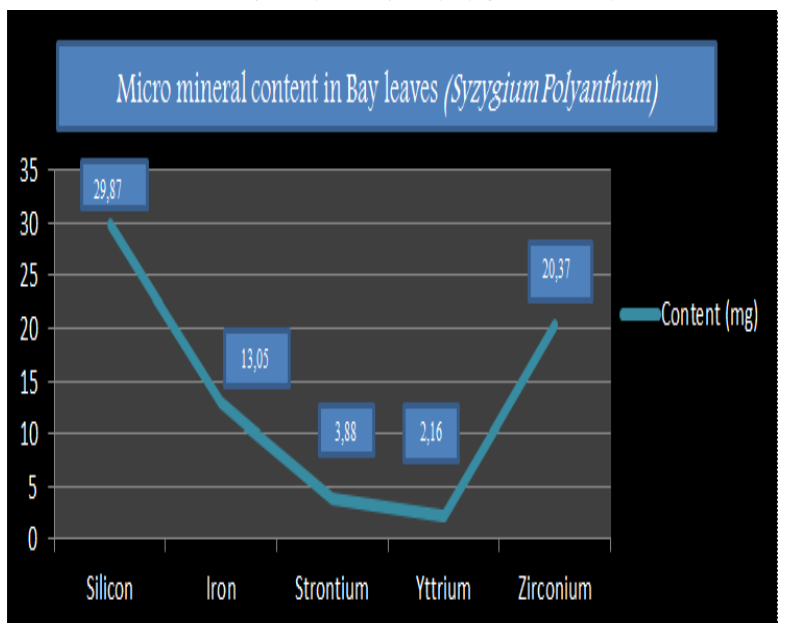

Fig. 2. Micro Mineral Content in Bay Leaves (Syzygium Polyanthum)

Based on the data in Figure 2, it can be concluded that there are several micro minerals found in Bay Leaves (Syzygium Polyanthum), including: Silicon (29.87 mg per gram), Iron (13.05 mg per gram), Strontium (3.88 mg per gram), Yttrium (2.16 mg per gram) and Zirconium (20.37 mg per gram). From this explanation, it can be seen that the highest micro minerals content in Bay Leaf (Syzygium Polyanthum) is silicon.

\section{Potential of Bay Leaf (Syzygium Polyanthum) To support of Mother's Nutrition}

TABLE I. POTENTIAL OF BAY LEAF (SYZYGIUM POLYANTHUM) FOR SUPPORT OF MOTHER'S NUTRITION (PER DAY)

\begin{tabular}{|c|c|c|c|c|c|c|}
\hline \multirow[t]{2}{*}{ No. } & \multirow{2}{*}{$\begin{array}{l}\text { Type of } \\
\text { mimeral on } \\
\text { Bay Leaf }\end{array}$} & \multirow{2}{*}{$\begin{array}{l}\text { Mimerals } \\
\text { content on } \\
\text { Bay Leaf }\end{array}$} & \multicolumn{2}{|c|}{ RDA } & \multicolumn{2}{|c|}{$\begin{array}{l}\text { Percentage for support } \\
\text { Mother's Nutrition }\end{array}$} \\
\hline & & & Preguancy & Breastfeeding & Pregnancy & Breastfeeding \\
\hline 1. & Calcrum & 751.25 & 1300 & 1300 & 57.7 & 57.7 \\
\hline 2. & Potassium & 287.5 & 4700 & 5100 & 6.1 & 5.6 \\
\hline 3. & Magnesium & 48.75 & 350 & 310 & 13.9 & 15.7 \\
\hline 4. & Phosphor & 25.12 & 700 & 700 & 3.5 & 3.5 \\
\hline 5. & Iron & 13.05 & 26 & 32 & 50.1 & 40.7 \\
\hline
\end{tabular}

Based on the table 1, several types of minerals and their contents have been described which are calculated to determine the potential of the Bay Leaf (Syzygium Polyanthum) for nutritional support in pregnancy and breastfeeding women. The data cannot describe all types of minerals related to specific minerals demand data not specifically explained. From this table, it can be seen that several types of maternal nutritional needs can be fulfilled with Bay Leaves (Syzygium Polyanthum), including: Calcium, Potassium, Magnesium, Phosphorus and Iron.

\section{DISCUSSION}

Based on the data that has been described, calcium becomes a potential macromineral substance to support the needs of pregnant and breastfeeding woman. Calcium in bay leaves can meeting the needs of pregnant and breastfeding women around $57.7 \%$ per day. Some common benefits of calcium are bone and tooth growth, regulating blood clotting, muscle contraction and relaxation, preventing osteoporosis, glycogen storage and the circulation functions of the brain and nerve system [18].

In preventing osteoporosis, it is very necessary to take consideration to lifestyle because it is very influential on bone mass such as eating foods that contain lots of calcium. The average calcium consumption of Indonesian people is also low, which is around $254 \mathrm{mg}$ per day which is only a quarter of the international standard. Important precautions are taken early, such as women of childbearing age (including pregnant and breastfeeding women) between 1549 years, especially before the woman is married and has children, because about 30 grams of calcium from the mother are able to be given to the fetus. Low calcium intake during pregnancy can cause disruption of mobilization of the mother's skeleton to support fetal needs.

In addition, insufficient calcium intake can increase the risk of bone loss during pregnancy and reduce postpartum bone recovery [19]. Longitudinal studies of calcium metabolism during pregnancy show that maternal calcium absorption increases significantly during the second and third trimesters. Even with a high absorption rate, fetal needs is up in the third trimester with $350 \mathrm{mg}$ per day requirements which may not be supported by chronic low calcium consumption ( $<600 \mathrm{mg}$ per day) because the total calcium absorbed is less than the amount needed.

Based on the results of the research also found those bay leaves contained Magnesium of $48.75 \mathrm{mg}$, which has the potential to support the mineral, needs per day of $13.9 \%$ for pregnant and $15.7 \%$ for breastfeeding women. Magnesium is 
a vasodilator in regulating blood pressure and as an inhibitor of contraction of vascular smooth muscle. Inadequate magnesium intake causes narrowing of the arterial and capillary walls so that blood pressure increases. Magnesium also has a role in producing vasodilator prostacyclin and NO (nitric oxide) by modulating the reactivity and movement of blood vessels [20] and can reduce dysmenorrhea pain [21]. In retrospective studies have reported that magnesium supplementation during pregnancy is strongly associated with a reduced risk of fetal growth retardation and preeclampsia. In addition, a cross-sectional study of food intake at the end of the first trimester of pregnancy reported that high magnesium intake was strongly related to enhancement of infant birth weight [22].

For micro mineral, bay leaves contain Fe (iron) which has the potential to support the needs of pregnant and breastfeeding women. The content of $\mathrm{Fe}$ (iron) in bay leaves can supply the needs of pregnant by $50.1 \%$ and breastfeeding woman by $40.7 \%$. The body needs iron which it is functions for oxygen synthesis in transporting proteins, especially hemoglobin and myoglobin and for the formation of heme enzymes and other iron-containing enzymes involved in electron transfer and oxidation reduction [23]. Most of the iron is in the form of hemoglobin $(\mathrm{Hb})$ which functions in the blood to carry oxygen from the lungs to all body tissues. After that, iron has a function to take back carbon dioxide from all cells to the lungs to be exhaled from the body. Iron also has an important role for immunity in the process of formation of lymphocyte cells [24]. During pregnancy, iron has an important role in the transport of oxygen by red blood cells/erythrocyte (RBC), energy production, growth and development have important role in the process of homeostasis for the mother and fetus [25]. Other research also shown that although breast milk is not the best source of iron, the quality of breast milk is strongly influenced by maternal iron reserves.

Based on the discussion, it can be concluded that bay leaves have the potential to support the mineral needs of pregnant and breastfeeding women.

\section{CONCLUSION}

The analysis shows that there are several mineral compositions in bay leaves, including: $\mathrm{Mg}, \mathrm{Si}, \mathrm{P}, \mathrm{S}, \mathrm{Cl}, \mathrm{K}$, $\mathrm{Ca}, \mathrm{Fe}$ and $\mathrm{Sr}$ which are needed by pregnant and breasfeeding women. Potential minerals in bay leaves that most significant to support the needs of pregnant and breastfeding women are calcium $(57.7 \%$ per day), Magnesium (13.9\% for pregnant women and $15.7 \%$ for breastfeeding woman) and iron $(50.1 \% / g$ for pregnant and $40.7 \% / \mathrm{g}$ for breastfeeding woman).

Comparison of the effectiveness of the extract and nano processes in producing $\mathrm{Fe}$ is $0.44 \mathrm{mg} / 100$ gram extract, while nano $13.05 \mathrm{mg} / 1$ gram. Nano process produces 29.66 times more $\mathrm{Fe}$ (iron) than extract. Other minerals cannot be compared.

\section{REFERENCES}

[1] Simanjuntak DH, Sudaryati E. Gizi pada Ibu Hamil dan Menyusui Univ Sumatera Utara. 2011;(Gizi pada Ibu hamil dan menyusui):7882.
[2] Radharisnawati NK, Kundre R. Hubungan Pemenuhan Kebutuhan Gizi Ibu Dengan Kelancaran Air Susu Ibu (Asi) Pada Ibu Menyusui Di Puskesmas Bahu Kota Manado. J Keperawatan. 2017;5(1).

[3] Siti muliawati. Faktor penyebab ibu hamil kurang energi kronis di puskesmas sambi kecamatan sambi kabupaten boyolali tahun 2012. J infokes apikes citra med semarang. Available from: https://www.ejurnalinfokes.apikescm.ac.id/index.php/infokes/article/v iew/115/112

[4] Gustirini R. Suplementasi Kalsium Pada Ibu Hamil Untuk Mengurangi Insidensi Preeklampsia Di Negara Berkembang. J Kebidanan. 2019;8(2):151.

[5] Devita H, Amran VYA. Hubungan Kadar Magnesium Dengan Kejadian Preeklamasi Pada Ibu Hamil Trimester III Di Rsup Dr. M. Djamil Padang Tahun 2015. J Kesehat Masy Andalas. 2017;10(2):136

[6] Salmariantity. Faktor- faktor yang Berhubungan dengan Anemia pada Ibu Hamil di Wilayah Kerja Puskesmas Gajah Mada Tembilahan Kabupaten Indragiri Hilir tahun 2012. Fakultas Kedokteran Universitas Indonesia. Jakarta; 2012.

[7] Astriana W. Kejadian Anemia pada Ibu Hamil Ditinjau dari Paritas dan Usia. J Aisyah J Ilmu Kesehat. 2017;2(2):123-30.

[8] World Health Organization. Haemoglobin concentrations for the diagnosis of anaemia and assessment of severity. Haemoglobin Conc diagnosis anaemia Assess Sev Vitam Miner Nutr Inf Syst Geneva, SwitzerlandAuthor. 2011:1-6

[9] Stevens GA, Finucane MM, De-Regil LM, Paciorek CJ, Flaxman SR, Branca F, et al. Global, regional, and national trends in haemoglobin concentration and prevalence of total and severe anaemia in children and pregnant and non-pregnant women for 1995-2011: A systematic analysis of population-representative data. Lancet Glob Heal. 2013;1(1):16-25.

[10] Siddiqui MZ, Goli S, Reja T, Doshi R, Chakravorty S, Tiwari C, et al. Prevalence of Anemia and Its Determinants Among Pregnant, Lactating, and Nonpregnant Nonlactating Women in India. SAGE Open. 2017;7(3):1-10.

[11] Maharani H. Faktor-Faktor Yang Berhubungan Dengan Status Gizi Ibu Menyusui Di Wilayah Kerja Puskesmas Kedungmundu Kota Semarang. J Kesehat Masy. 2016;4(3):187-96.

[12] Adyani K, Anwar AD, Rohmawaty E. Peningkatan Kadar Hemoglobin dengan Pemberian Ekstrak Daun Salam (Syzygium Polyanthum (Wight) Walp) pada Tikus Model Anemia Defisiensi Besi. Maj Kedokt Bandung. 2018;50(3):167-72.

[13] Silalahi M. Syzygium polyanthum (Wight) Walp.(Botani, Metabolit Sekunder dan Pemanfaatan). J Din Pendidik. 2017;10(1):187-202.

[14] Novira PP, Febrina E. Tinjauan Aktivitas Farmakologi Ekstrak Daun Salam (Syzygium polyanthum (Wight.) Walp). Farmaka. 2018;16(2):288-97.

[15] Jumaat SR, Tajuddin SN, Sudmoon R, Chaveerach A, Abdullah UH, Mohamed R. Chemical constituents and toxicity screening of three aromatic plant species from Peninsular Malaysia. BioResources. 2017;12(3):5878-96.

[16] Jumini S. Nanoteknologi Manivestasi Nanosciences. J Penelit dan Pengabdi Kpd Masy UNSIQ. 2017;4(2):199-206.

[17] Ansari SH, Islam F, Sameem M. Influence of nanotechnology on herbal drugs: A Review. J Adv Pharm Technol Res. 2012;3(3):142-6.

[18] Shita ADP, Sulistiyani. Pengaruh Kalsium Terhadap Tumbuh Kembang Gigi Geligi Anak. Stomatognatic (J K $\mathrm{G}$ Unej). 2010;7(3):40-4

[19] Regina J, Setiawati EP, Hidajat NN. Hubungan Pengetahuan dan Sikap dengan Tindakan Pencegahan Osteoporosis pada Wanita Usia Subur di Kecamatan Babakan Ciparay Kota Bandung Measure Among Woman of Reproductive Age. 2019;4:140-6.

[20] Ilma AD WY. Pengaruh pemberian jus mentimun dan tomat terhadap tekanan darah perempuan overweight dan obesitas. J Nutr Coll. 2015;4(2):87-281.

[21] Tih F, Azaria C, Gunadi JW, Rumanti R, Susanto, Alfred Tri Tyrani. Effect of Calcium and Magnesium Supplements on Primary Dysmenorrhea and Premenstrual Syndrome in 19 - 23 Years Old Women. Glob Med Heal Commun. 2016;5(65):159-66.

[22] Makrides M, Crosby DD, Bain E, Crowther CA. Magnesium supplementation in pregnancy. Cochrane Database Syst Rev. 2014;2014(4) 
[23] Abbaspour N, Hurrell R, Kelishadi R. Review on iron and its importance for human health. J Res Med Sci. 2014;19(2):164-74.

[24] Ridwan E. Kajian Interaksi Zat Besi dengan Zat Gizi Mikro Lain dalam Suplementasi. J Penelit Gizi dan Makanan. 2012;35(1):49-54.
[25] Brannon PM, Taylor CL. Iron supplementation during pregnancy and infancy: Uncertainties and implications for research and policy. Nutrients. 2017;9(12):1-17 